\title{
Malignant progression of laryngeal papilloma associated with human papilloma virus type 6 (HPV-6) DNA
}

\author{
A P ZAROD, * J D RUTHERFORD,$\dagger$ G CORBITT $\ddagger$ \\ From the *Department of Otolaryngology, Manchester Royal Infirmary, Christie Hospital and Holt Radium \\ Institute, Manchester, the $\uparrow$ Pathology Department, The Stopford Building, University of Manchester, and the \\ $\ddagger$ North Manchester Regional Virus Laboratory, Manchester Royal Infirmary
}

SUMMARY A case of laryngeal squamous papilloma in the early stages of development showed histological features suggestive of virus infection. Five years later positive evidence of HPV-6 infection was obtained at a time when the lesion had developed into a squamous cell carcinoma. It is concluded that this case represents a complete example of the virus to papilloma to carcinoma sequence, and as far as is known, is the first reported case of its kind in the larynx.

For over 100 years papilloma has been recognised as being the most common benign tumour of the larynx. Because of the morphological similarity to papillomas which occur in other sites where a viral origin has been confirmed, laryngeal papilloma has long been considered to be of viral origin. Only recently has the presence of papilloma virus (HPV) been confirmed without doubt and established to be the same virus which infects the tissues of the genital tract.

In 1880 Mackenzie was the first to record that lesions in children tend to be multiple and recurrent whereas in adults they tend to be single and curable with one excision.' By 1973 there were conflicting reports on the presence of viral particles in laryngeal papilloma when examined by electron microscopy. ${ }^{23}$ In 1980 papilloma virus capsid antigen was detected by Lack et al using immunoperoxidase techniques. ${ }^{4}$ In 1982 Mounts et al showed that viral genomes were closely related to papilloma virus HPV type 6, using DNA hybridisation techniques. Human papilloma virus type 6 has been linked with oral, genital, and laryngeal papillomas. In 1983 Gissman et al found HPV type 11 in laryngeal papilloma and HPV type 6 and HPV type 11 in genital papillomas. ${ }^{6}$ Carcinomatous change in pre-existing papillomas from other sites and species has also been observed. ${ }^{7-9}$

Accepted for publication 25 September 1987

\section{Case report}

A 72 year old female non-smoker had had repeated microlaryngoscopic procedures for recurrent laryngeal papillomas since the age of 65 . In 1984 when the carbon dioxide laser became available at the Christie Hospital and Holt Radium Institute she was referred for further treatment by laser vapourisation. Previous procedures for recurrent hoarseness due to clinically and histologically benign laryngeal papillomas consisted of microlaryngoscopic excision of tumour from the left vocal cord.

At the time of laser treatment papilloma was noted covering the anterior one third of the left vocal cord, the base of the epiglottis under the tubercle encroaching on the anterior comissure, and the floor of the left ventricle. Two biopsy specimens were taken from the anterior one third of the left vocal cord using cup forceps. One specimen was sent for conventional histological staining and the other for HPV typing. The residual papilloma was vapourised by the laser. Results showed the presence of invasive squamous cell carcinoma and HPV type 6 infection.

Although the staging was probably that of a $T_{1} N_{0} M_{0}$ laryngeal carcinoma, she was clinically classified as $\mathrm{T}_{2} \mathbf{N}_{0} \mathbf{M}_{0}$ because papillomatous infection was not limited to one vocal cord. She received a radical course of radiotherapy and remained disease free at the time of writing. 




Fig 1 Biopsy specimen from 1979 showing benign squamous papilloma.

\section{Pathology}

Sections of the laryngeal biopsy specimens from 1979, 1980, 1981 and 1984 were reviewed. All were substantial cup forceps biopsy specimens. The first two were of benign papillomata and both showed koilocytotic atypia; neither showed the key features of verrucous carcinoma as outlined by Michaels ${ }^{10}$ - that is, keratinisation, parakeratosis, mononuclear inflammatory cell infiltrate of the connective tissue core, crowding of basal cells and wide fields of large intermediate cells (figs 1 and 2). The third specimen from 1981 showed koilocytosis and obvious cellular atypia (fig 3 ). The 1984 biopsy specimen showed unequivocal evidence of well differentiated squamous cell carcinoma showing keratin pearls and microinvasion (fig 4). All four specimens were taken from the left vocal cord. Using DNA hybridisation techniques, dot blotting, and Southern transfer analysis ${ }^{11}$ human papilloma virus type 6 (HPV-6) was isolated from the final biopsy specimen taken in 1984.

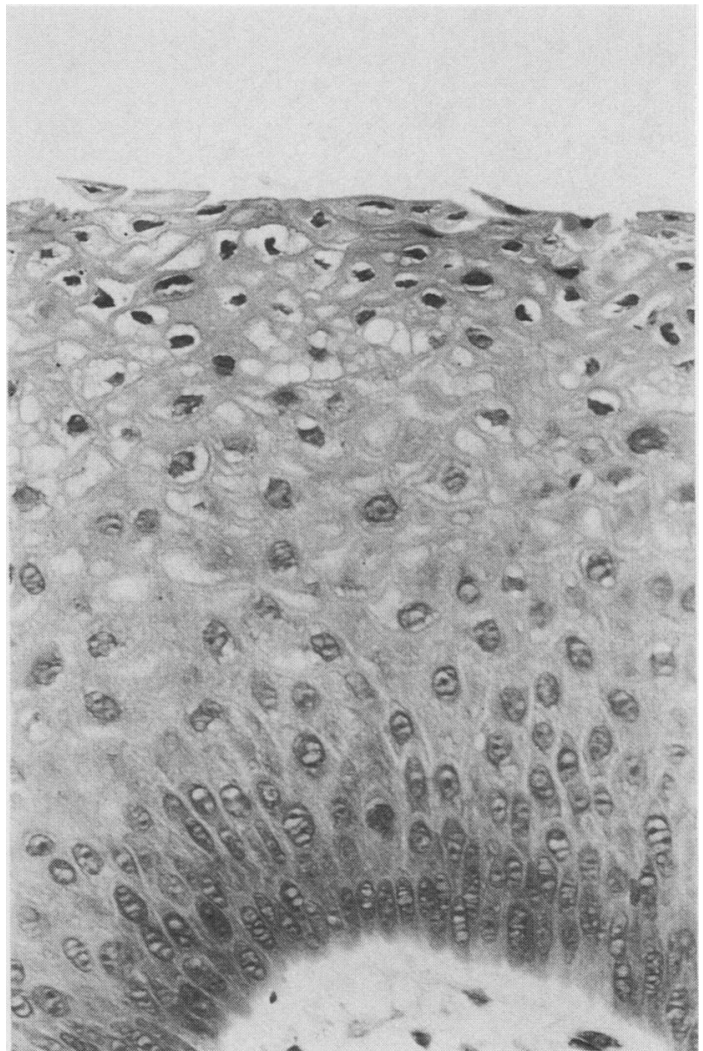

Fig 2 Biopsy specimen from 1979 showing koilocytic atypia characterised by typical brick shaped nuclei and perinuclear halo.

\section{Discussion}

Benign and malignant tumours associated with viruses are a well established phenomenon in animals. ${ }^{12}$ Bovine papilloma virus BPV-4 has been detected only in benign lesions. BPV-1 and BPV-2, however, have been shown to transform cells and produce malignant tumours in a wide variety of species. ${ }^{13}$ The Shope papilloma virus has been identified in both benign and malignant tumours. ${ }^{14}$ In man epidermodysplasia verucciformis HPV 5 or 8 has been detected in $82 \%$ of invasive lesions in which it was possible to detect HPV genome. $^{15}$

Benign to malignant transformation as a result of viral infection is gradually being accepted as a process which may occur in man. Current interest is also centered on HPV virus in cervical carcinoma. Crum et al concluded that the presence of HPV-16 correlated with the presence of mitotic figures in flat warts of the cervix and that these warts were a precursor of invasive cancer of the cervix. ${ }^{16}$ In some veruccous carcinomas 


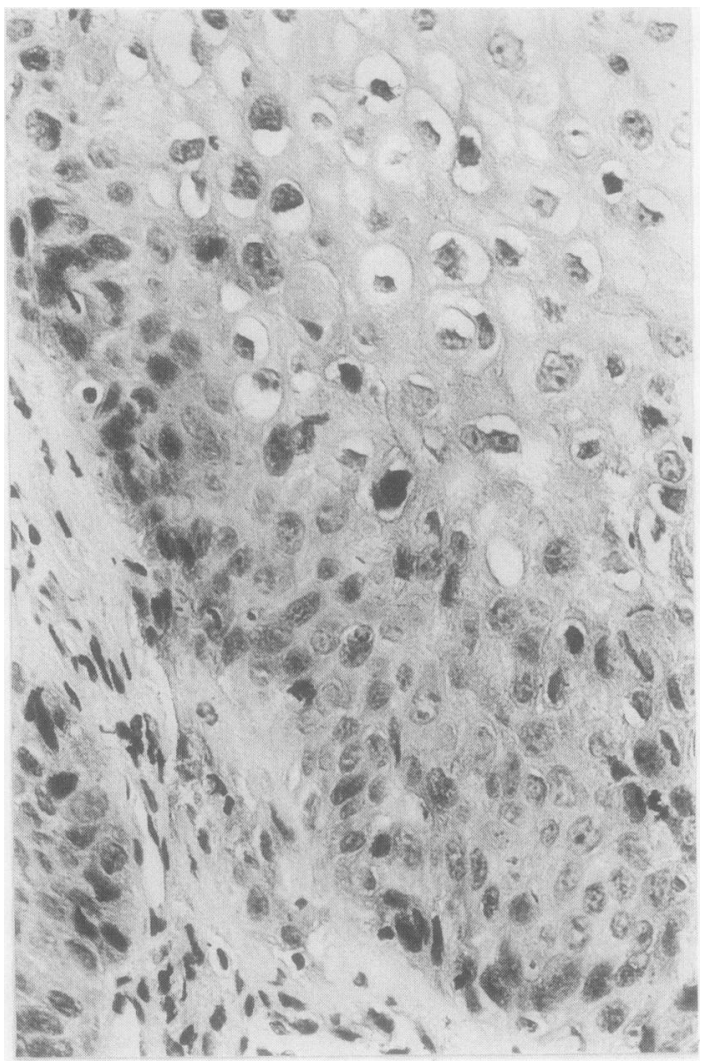

Fig 3 Biopsy specimen from 1981 showing koilocytosis and cellular atypia.

of the genital tract HPV-6 and HPV-11 sequences have been shown ${ }^{17}$ and some vulval carcinomas contain sequences related to HPV-16. ${ }^{18}$ Our case seems to represent an example of virus to papilloma to carcinoma sequence in the human larynx.

Although verrucous carcinoma may be mistaken for squamous papilloma, careful review of the early specimens and comparison with known squamous papillomas confirmed our belief that the original biopsy specimens were of genuine squamous papilloma.

Koilocytosis as a marker of viral infection in mucosal surfaces is well recognised. ${ }^{10}$ An aetiological viral role in our case was implicated by the fact that koilocytosis was seen in the biopsy specimen taken when the patient first presented in 1979 and in subsequent specimens taken in 1980 and 1981. Although it is possible to show the presence of viral particles by both electron microscopy ${ }^{2}$ and immunoperoxidase methods, ${ }^{4}$ these tend to be time consuming,

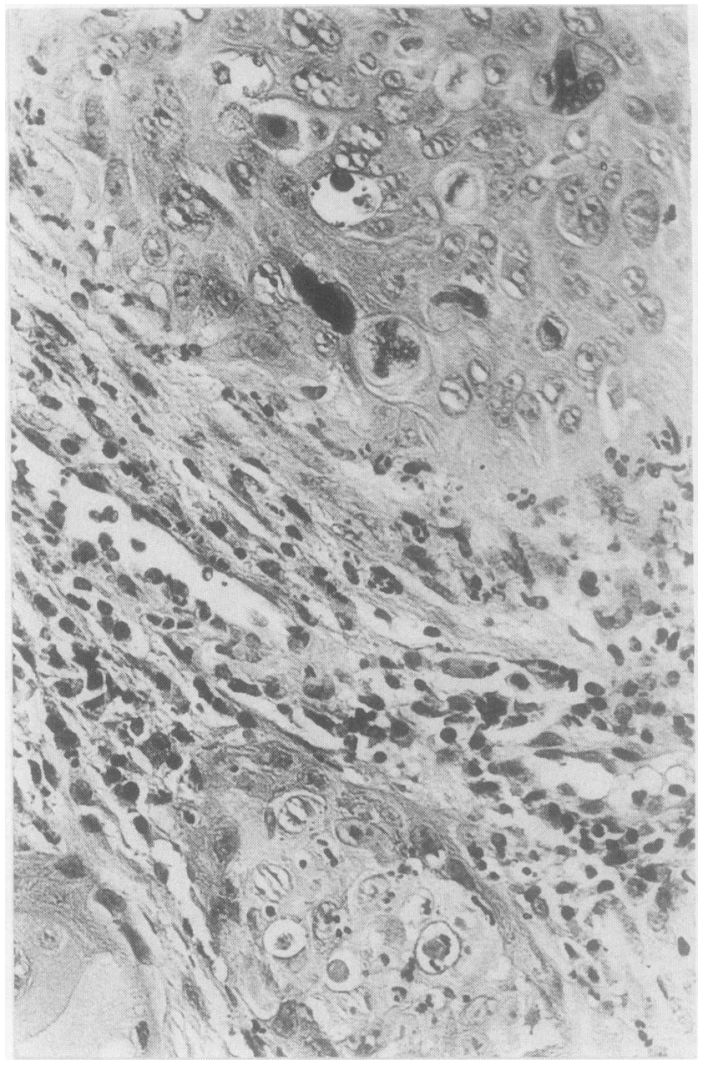

Fig 4 Biopsy specimen from 1984 showing squamous cell carcinoma characterised by nuclear pleomorphism, abnormal mitotic figures, and microinvasion.

lack sensitivity, and do not give a high yield of positive results. In tumour tissue viral genome expression is usually limited, and production of virus specific protein is either very small or non-existent. Recent advances in DNA hybridisation techniques give a sensitive technique for viral DNA detection and HPV typing. In our patient the presence of HPV-6 DNA was doubly confirmed by using dot blotting and Southern transfer analysis.

It is interesting to note that the type of papilloma virus isolated here was of a different type (HPV-6) to those commonly associated with carcinoma of the cervix (HPV-16), ${ }^{16}$ although it is of the same type as one of those associated with benign condylomata of the uterine cervix (HPV-6 and HPV-11). ${ }^{6}$

In this case, malignant change occurred without any increase in symptoms. It is therefore recommended that all specimens be sent for histological examination and that pathologists should specifically look for features of viral infection and early atypia and 
emphasise the presence of these in biopsy reports so that clinicians may be alerted to the risk of cancerous change.

We would point out that the adult onset papilloma is histologically indistinguishable from the juvenile type $^{19}$ but behaves in a different way clinically. The juvenile form is associated with florid papillomatosis but no malignant change unless the lesion is irradiated..$^{20}$ The papilloma viruses implicated (types 6 and 11) are the same as those seen in benign condylomata of the cervix, implying that transmission may occur during passage down the birth canal. The adult type, by contrast, is less florid clinically but more likely to undergo spontaneous malignant change. ${ }^{21}$ Using cytological hybridisation techniques, Brichacek et al associated Epstein-Barr virus with supraglottic laryngeal carcinoma in three of five patients with Epstein-Barr virus antibodies. ${ }^{22}$ In our case of glottic carcinoma associated with a previous history of laryngeal papilloma and HPV-6 infection the malignant change may have induced by the virus.

We confirm the association of human papilloma virus with laryngeal papilloma and that carcinomatous change may take place in pre-existing benign papillomas. We believe that our case illustrates the link between these phenomena and postulate that the virus may be the initiating event in the papilloma to carcinoma sequence. This is analogous to the situation in the uterine cervix and adds further weight to the accumulating evidence implicating viruses as aetiological agents in cancers in man.

We thank $\mathrm{Mr} \mathbf{R} \mathbf{T}$ Ramsden for permission to report his patient who was subsequently treated under the care of $\mathrm{Mr} \mathrm{W} \mathrm{T}$ Farrington, the generosity of Dr R Dodge for loaning histological material, and the Research Grants Committee of the Central Manchester Health Authority for funding the DNA hybridisation studies.

\section{References}

1 Mackenzie M. Manual of diseases of the throat and nose. London: JA Churchill, 1880.

2 Svoboda DJ, Kirchner FR, Proud GO. Electron microscopic study of human laryngeal papillomatosis. Cancer Res 1963;23:1084-9.

3 Cook TA, Cohn AM, Brunschwig JP, Goepfert H, Butel JS, Rawls WE. Laryngeal papilloma: etiologic and therapeutic considerations. Ann Otol Rhinol Laryngol 1973;82:649-55.

4 Lack EE, Jenson AB, Smith HG, Healy GB, Pass F, Vawter GF.
Immunoperoxidase localisation of human papillomavirus in laryngeal papillomas. Intervirology 1980;14:148-54.

5 Mounts P, Shah KV, Kashmah H. Viral etiology of juvenile and adult onset squamous papilloma of the larynx. Proc Natl Acad Sci USA 1982;79:5425-9.

6 Gissman L, Wolnik L, Ikenberg H, Koldovsky U, Schnurch HG, zur Hausen H. Human papillomavirus type 6 and 11 DNA sequences in genital and laryngeal papillomas and in some cervical cancers. Proc Natl Acad Sci USA 1983;80:560-3.

7 Grussendorf E, Gahlen W. Metaplasia of a verucca vulgaris into a spinocellular carcinoma. Dermatologica 1975;150:295-9.

8 Syverton JT. The pathogenesis of the rabbit papilloma to carcinoma sequence. Ann NY Acad Sci 1952;54:1126-40.

9 Gisser SD. Papovavirus and squamous cell carcinoma. Hum Pathol 1981;12:190-3.

10 Michaels L. Pathology of the Larynx. Heidelberg: Springer-Verlag, 1984, 159-73, 258-65.

11 Southern EM. Detection of specific sequences among DNA fragments separated by gel electrophoresis. J Mol Biol 1975;98:503-17.

12 McNeill PE, Laird HM, Jarrett WFH, et al. In: Essem M, Todaro $\mathrm{G}$, zur Hausen $\mathrm{H}$, eds. Viruses in naturally occurring cancers. New York: Old Spring Harbour Laboratory, 1981:215.

13 Lancaster W, Olsen C. Animal papilloma viruses. Microbiol Rev 1982;46:191-207.

14 Stevens JG, Wettstein FO. Multiple copies of Shope virus DNA are present in cells of benign and malignant non-virus-producing neoplasms. J Virol 1979;30:891-8.

15 Orth G, Jablonska S, Jarzabek-Chorzelska M, et al. Characteristics of the lesions and risk of malignant conversion associated with the type of human papillomavirus involved in epidermodysplasia verucciformis. Cancer Res 1979;39:1074-82.

16 Crum CP, Ikenberg H, Richart RM, Gissman L. Human papillomavirus type 16 and early cervical neoplasia. $N$ Engl $J$ Med 1984;310:880-3.

17 Durst M, Gissman L, Ikenberg H, zur Hausen H. A Papilloma virus DNA from a cervical carcinoma and its prevalence in cancer biopsy samples from different geographic regions. Proc Natl Acad Sci USA 1983;80:3812-15.

18 Green M, Brackmann K, Sanders P, et al. Isolation of human papillomavirus from a patient with epidermodysplasia verruciformis: presence of related viral DNA genomes in human urogenital tumours. Proc Natl Acad Sci USA 1982;79:4437-41.

19 Capper JWR, Bailey CM, Michaels L. Squamous papillomas of the larynx in adults: a review of 63 cases. Clin Otolaryngol 1983;8:109-18.

20 Majoros M, Devine KD, Parkhill EM. Malignant transformation of benign laryngeal papillomas in children after radiation therapy. Surg Clin North Am 1963;43:1049-61.

21 Mounts P,Kashima H. Association of human papilloma virus subtype and clinical course in respiratory papillomatosis. Laryngoscope 1984;94:28-33.

22 Brichacek B, Hirsch I, Sibl O, Vilikusova E, Vonka V. Association of some supraglottic laryngeal carcinomas with EB virus. Int $J$ Cancer 1983;32:193-7.

Requests for reprints to: Dr G Corbitt, Principal Microbiologist, North Manchester Regional Virus Laboratory, Manchester Royal Infirmary, Oxford Road, Manchester M13 9WL, England. 